\title{
Biogeochemistry and limnology in Antarctic subglacial weathering: molecular evidence of the linkage between subglacial silica input and primary producers in a perennially ice-covered lake
}

\author{
Yoshinori Takano ${ }^{1 *}$, Hisaya Kojima², Eriko Takeda², Yusuke Yokoyama ${ }^{1,3}$ and Manabu Fukui ${ }^{2}$
}

\begin{abstract}
We report a 6,000 years record of subglacial weathering and biogeochemical processes in two perennially ice-covered glacial lakes at Rundvågshetta, on the Soya Coast of Lützow-Holm Bay, East Antarctica. The two lakes, Lake Maruwan Oike and Lake Maruwan-minami, are located in a channel that drains subglacial water from the base of the East Antarctic ice sheet. Greenish-grayish organic-rich laminations in sediment cores from the lakes indicate continuous primary production affected by the inflow of subglacial meltwater containing relict carbon, nitrogen, sulfur, and other essential nutrients. Biogenic silica, amorphous hydrated silica, and DNA-based molecular signatures of sedimentary facies indicate that diatom assemblages are the dominant primary producers, supported by the input of inorganic silicon (Si) from the subglacial inflow. This study highlights the significance of subglacial water-rock interactions during physical and chemical weathering processes and the importance of such interactions for the supply of bioavailable nutrients.
\end{abstract}

Keywords: Antarctic ice sheet; Subglacial biogeochemistry; Subglacial limnology; Sedimentary record; Siliceous primary producer

\section{Background}

Subglacial Antarctic lakes were first identified by radioecho sounding in the late 1960s (Robin et al. 1970; Oswald and Robin 1973). Since then and especially during the past two decades, researchers have identified numerous subglacial lakes (e.g., Kapitsa et al. 1996; Siegert et al. 1996; Jouzel et al. 1999; Karl et al. 1999; Priscu et al. 1999; Christner et al. 2006) and extensive networks of subglacial meltwater channels in Antarctica (e.g., Anderson et al. 2002; Wingham et al. 2006). Siegert and coworkers compiled an inventory of 145 subglacial lakes beneath the East Antarctic Ice Sheet and the West Antarctic Ice Sheet (EAIS and WAIS) (Siegert 2000; Siegert et al. 2005). The subglacial water, which initially derives from melting caused by geothermal heat (heat

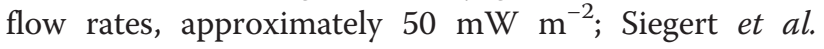

\footnotetext{
* Correspondence: takano@jamstec.go.jp

'Department of Biogeochemistry, Japan Agency for Marine-Earth Science and Technology (JAMSTEC), 2-15 Natsushima, Yokosuka, Kanagawa 237-0061, Japan Full list of author information is available at the end of the article
}

2012), is involved in various water-rock interaction processes beneath the ice sheet, and these interactions play important roles in the supply of nutrients, including trace metals, to organisms in Antarctic environments. For example, silicon $(\mathrm{Si})$ is one of the critical elements limiting the growth of Antarctic diatoms (e.g., Nelson and Treguer 1992), likewise nitrogen and other elements (e.g., Hutchins and Bruland 1998). Moreover, glacial input of particulate and dissolved Fe is essential to biological productivity in the Southern Ocean (Raiswell and Canfield 2012). In addition to the nutrient contributed by seasonal snowmelt (Hodson 2006), subglacial meltwater flowing through channels may also influence the productivity and diversity of microbial communities by controlling the concentrations of nutrients and the physicochemical conditions of glacial environments (e.g., Tranter et al. 2005; Esposito et al. 2006; Mikucki et al. 2009; Bentley et al. 2011).

At the margins of the EAIS and WAIS, there are a number of locations where former subglacial lakes have 
emerged from beneath the ice after the deglaciation since the Last Glacial Maximum (LGM, ca. 20 ka; Yokoyama and Esat 2011: lake settings, e.g., Hodgson et al. 2006; Hodgson et al. 2009; Verleyen et al. 2011). Glacial lakes affected by the input of subglacial water can be observed at the retreating margins of the Antarctic ice sheet. In the Rundvågshetta area on the Soya Coast of Lützow-Holm Bay, East Antarctica (Figure 1a), freshwater flows from the subglacial drainage channels of the EAIS (Anderson et al. 2002, and literature therein). The objective of this study was to examine the interactions between the limnology of the subglacial water input and microbiological responses to the subglacial water discharged into a perennially icecovered glacial lake at Rundvågshetta (i.e., Lake Maruwan Oike) over the last 6,000 years. By combining geochemical data and the molecular signatures preserved in sediment core samples, this study aimed to clarify the primary factors controlling biological facies patterns in subglacialwater-fed lakes.

\section{Methods}

\section{Geological setting of the sampling sites}

Since the initial work by Yoshikawa and Toya (1957) and Murayama (1977), studies undertaken in the Lützow-Holm Bay area of East Antarctica have contributed further insight into the limnology of Antarctic lakes and the relative sea-level changes that occurred during the Holocene. Imura et al. (2003) described a range of lake types in the Soya Coast region, including freshwater lakes affected by continental glaciers and saline lakes that evaporated after their isolation from seawater during the Holocene glacio-isostatic uplift. Kudoh and Tanabe (2014) reviewed the limnology and ecology of benthic microbial assemblages from saline to glacial lakes in this area. The Holocene marine limit along the Soya Coast is estimated to have been approximately $18 \mathrm{~m}$ above the mean sea level (AMSL), based on radiocarbon analyses of in situ bivalve fossils from raised beach deposits (Laternula elliptica; Miura et al. 1998). Cosmogenic-radionuclide-based dating of raised beach exposures showed that Holocene deglaciation occurred locally on the Soya Coast at ca. $10 \mathrm{ka}$ (Yamane et al. 2011). Bassett et al. (2007) also compared predictive models of glacio-isostatically induced relative sea-level changes at seven other locations around the Antarctic coast, as well as on the Soya Coast.

Rundvågshetta $\left(69^{\circ} 54.5^{\prime} \mathrm{S}, 39^{\circ} 02^{\prime}\right.$ E; Figure 1a) is a rock headland at the southwest margin of the Rundvåg Glacier (e.g., Sawagaki and Hirakawa 1997; Miura et al. 1998). Figure $1 \mathrm{~b}$ shows the electric conductivity $\left(\mathrm{mS} \mathrm{m}^{-1}\right)$ of the study site, confirming the origin of the lake water inflow. Two lakes on the headland, Lake Maruwan Oike (hereafter, L. Maruwan), with a water level $8 \mathrm{~m}$ AMSL (data from the Geographical Survey Institute 1984), and Lake Maruwan-minami (hereafter, L. Maruwan-minami), with a water level $>8 \mathrm{~m}$ AMSL (the overflow channel of $\mathrm{L}$. Maruwan-minami flows into L. Maruwan; see Figure 2a), provide interesting localities in which to evaluate the influence of subglacial water input on the biogeochemical and sedimentological characteristics of the lakes into which it is discharged (Table 1). It has been reported that the maximum thickness of the surface ice in the Soya Coast region is less than $2 \mathrm{~m}$ (Imura et al. 2003). Figure 2 shows lakes Maruwan and Maruwan-minami and the surrounding features, including Rundvåg Glacier, a lateral moraine close to the glacier, and the outflows of lakes Maruwan and Maruwan-minami. We also observed a number of erratic boulders derived from glacial transport processes.

Lacustrine sediments were collected using push-type corers (diameter, $<8 \mathrm{~cm}$; see the core images in Figure 3 ) during the 47th Japanese Antarctica Research Expedition (December 2005). The latitude and longitude of the sampling position in L. Maruwan (hereafter, sample Mw5S; core length, $156 \mathrm{~cm}$ ) were recorded with GPS as 69.54' $27.7^{\prime \prime} \mathrm{S}$ and $39.02^{\prime} 46.7^{\prime \prime} \mathrm{E}$, respectively. The water depth and the ice thickness at this site were 20.2 and $1.5 \mathrm{~m}$, respectively (cf. surface sediment description; Watanabe et al. 2013). We also collected lake sediments from L. Maruwan-minami (hereafter, sample Ms5S) as a reference site (see Additional file 1). The cores were cut into 3 to $10 \mathrm{~cm}$ intervals (to fit into the field refrigeration unit) and stored at 0 to $4^{\circ} \mathrm{C}$ for later geochemical analysis and at $-20^{\circ} \mathrm{C}$ for later molecular analysis.

\section{Geochemical analysis of sedimentary facies}

The major elements $\left(\mathrm{MgO}, \mathrm{Al}_{2} \mathrm{O}_{3}, \mathrm{SiO}_{2}, \mathrm{~K}_{2} \mathrm{O}, \mathrm{CaO}\right.$, $\mathrm{TiO}_{2}, \mathrm{MnO}$, and $\mathrm{Fe}_{2} \mathrm{O}_{3}$ ) were analyzed with X-ray fluorescence (XRF; JEOL JSX-3211; JEOL Ltd., Tokyo Japan), following Takano et al. (2012), and calibrated to Geological Survey of Japan (GSJ) standards (JA-1, JA-3, JB1a, JB-3, JG-2, JG-3, JGb-1, JP-1, JLK-1, JLs-1, JDo-1, JSI-1, JCh-1, JR-3, JMn-1, JSd-2, and JSd-3; Imai et al. 1995, 1999). The data presented represent the average values of duplicate analyses. Amorphous hydrated silica (opal-A) identified with X-ray diffraction (XRD; Mac Science Co., Ltd., Yokohama, Japan) was used as a proxy for amorphous biogenic silica derived from diatoms (siliceous primary producers; e.g., Kastner et al. 1977; Leng and Barker 2006), with DNA-based molecular signatures as supporting data (Takano et al. 2012). Color data were obtained with a digital color meter (Konica Minolta, Tokyo, Japan; SPAD 503) and revised Standard Soil Color Charts (Oyama and Takehara 2005).

The methods used for elemental and bulk isotopic analyses are described by Takano et al. (2012). Briefly, the analyses of carbon, nitrogen, and sulfur were performed 


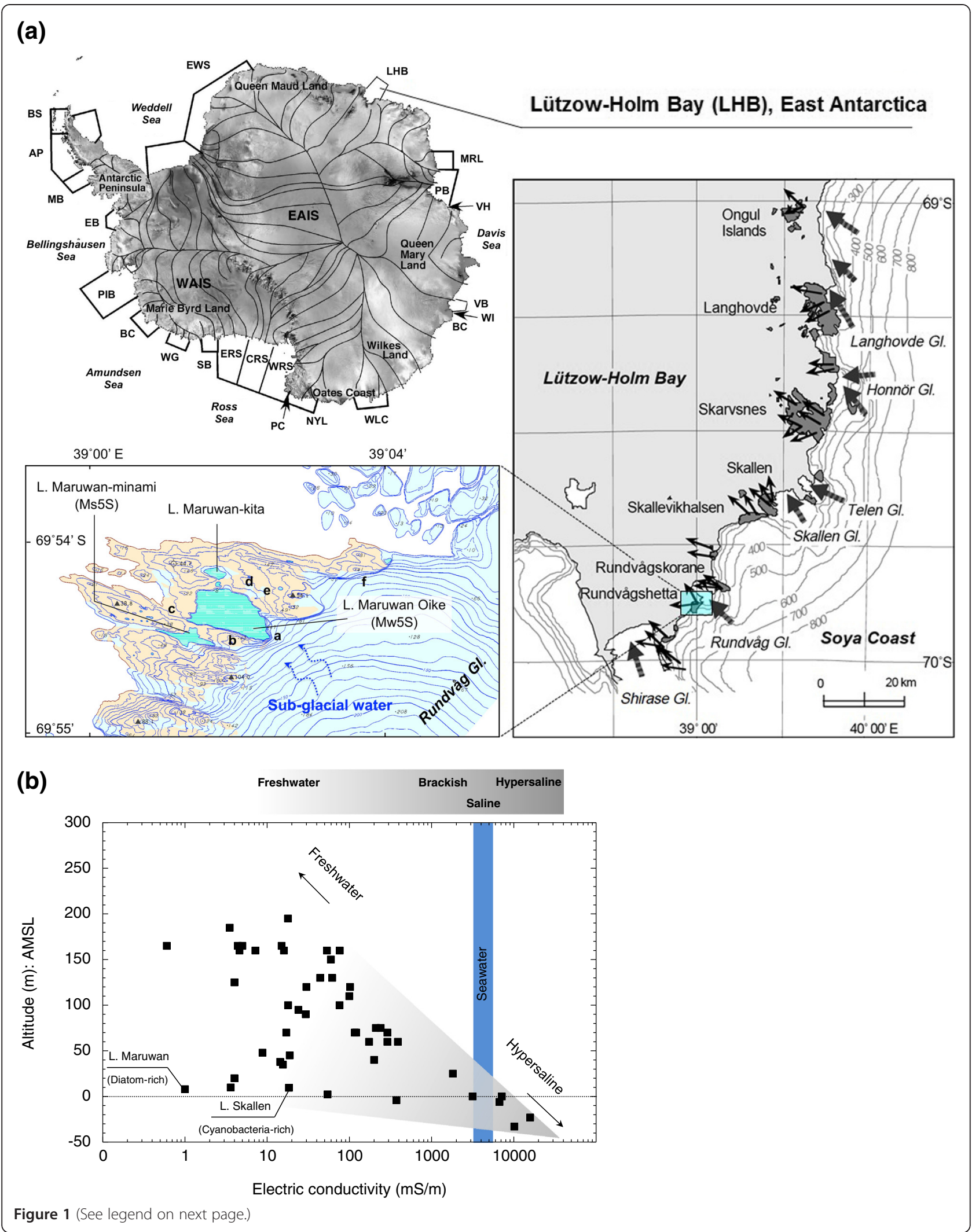


(See figure on previous page.)

Figure 1 Drainage map of the Antarctic Ice Sheet and electric conductivity ( $\mathrm{mS} \mathrm{m}^{-1}$ ) of the study site. (a) (upper left) Drainage map of the Antarctic Ice Sheet showing areas where marine and geological surveys are being conducted to record the extent of the Last Glacial Maximum (LGM). (right) Detail of the Soya coast, Lützow-Holm Bay, East Antarctica, showing the locations of ice-covered (white) and ice-free (shaded) areas at Rundvågshetta, Skallen, Skarvsnes, and Langhovde. Arrows show the flow directions of the present outlet glaciers (after Sawagaki and Hirakawa 1997). (lower left) Topography at Rundvågshetta, showing the locations of lakes Maruwan, Maruwan-minami, and Maruwan-kita. Labels a to $f$ indicate the locations of the images in Figure 2. NWWS, northwestern Weddell Sea; BS, Bransfield Strait; AP, Antarctic Peninsula; MB, Marguerite Bay; EB, Eltanin Bay; PIB, Pine Island Bay; BC, Bakutis Coast; WG, Wrigley Gulf; SB, Sulzberger Bay; WRS, Western Ross Sea; CRS, Central Ross Sea; ERS, Eastern Ross Sea; NVL, Northern Victoria Land; WLC, Wilkes Land Coast; PC, Pennell Coast; BC, Budd Coast; WI, Windmill Islands; PB, Petersen Bank; VB, Vincennes Bay; VH, Vestfold Hills; PB, Prydz Bay; MRL, Mac. Robertson Land; LHB, Lützow-Holm Bay; EWS, eastern Weddell Sea; SWS, southwestern Weddell Sea (modified from Anderson et al. 2002). (b) Diagram showing the altitudes of lakes (in meters above the mean sea level; AMSL) on the Soya Coast and electrical conductivities of lake waters (in $\mathrm{mS} / \mathrm{m}$ ) obtained by Imura et al. (2003), combined with data from L. Maruwan (diatom-rich microflora; this study) and L. Skallen (cyanobacteria-rich microflora; Takano et al. 2012). Note that the altitude data for L. Maruwan (8.0 m) and L. Skallen ( $9.64 \pm 0.02 \mathrm{~m}$ ) were referred from Geographical Survey Institute (1984) and Takano et al. (2012), respectively. See the limnological features for the numbers of lakes (Kudoh and Tanabe 2014). Seawater electrical conductivity (e.g., Cox et al. 1967; Lee et al. 2006), salinity (e.g., Koblinsky et al. 2003), and a variety of electrical conductivity measurements in hypersaline lakes (e.g., Williams and Sherwood 1994) are also given.

using a Micro CORDER JM10 (J-Science Lab Co., Ltd, Kyoto, Japan). Carbon and nitrogen isotopic ratios were determined using an elemental analyzer (Costech 4010 or Flash 2000)-isotope ratio mass spectrometer (Thermo Finnigan, Delta Plus, or Thermo Finnigan Delta V Advantage). Carbon and nitrogen isotopic compositions are expressed as per mil (\%o) deviations from the standard as:

$$
\begin{aligned}
\delta^{13} \mathrm{C}= & {\left[\left({ }^{13} \mathrm{C} /{ }^{12} \mathrm{C}\right)_{\text {sample }} /\left({ }^{13} \mathrm{C} /{ }^{12} \mathrm{C}\right)_{\text {standard }}-1\right] } \\
& \times 1,000(\% \text { vs. PDB }) \\
\delta^{15} \mathrm{~N}= & {\left[\left({ }^{15} \mathrm{~N} /{ }^{14} \mathrm{~N}\right)_{\text {sample }} /\left({ }^{15} \mathrm{~N} /{ }^{14} \mathrm{~N}\right)_{\text {standard }}-1\right] } \\
& \times 1,000(\% \text { vs. Air }),
\end{aligned}
$$

respectively.

The standard deviations for the carbon and nitrogen isotopic compositions obtained using authentic standard reagents (cf. Tayasu et al. 2011) were as follows: BG-A $\left(n=12, \quad \delta^{13} \mathrm{C}< \pm 0.26 \%, \quad \delta^{15} \mathrm{~N}< \pm 0.25 \%\right)$, BG-P $(n=6$, $\delta^{13} \mathrm{C}< \pm 0.05 \%$, $\left.\delta^{15} \mathrm{~N}< \pm 0.24 \%\right)$, and BG-T $\left(n=9, \delta^{13} \mathrm{C}\right.$ $< \pm 0.08 \%$ o, $\delta^{15} \mathrm{~N}< \pm 0.26 \%$ ) in the first validation and BG-A $\quad\left(n=10, \quad \delta^{13} \mathrm{C}< \pm 0.12 \%\right.$ o, $\left.\delta^{15} \mathrm{~N}< \pm 0.26 \%\right), \quad$ BG-P $\left(n=6, \delta^{13} \mathrm{C}< \pm 0.06 \%\right.$, $\left.\delta^{15} \mathrm{~N}< \pm 0.18 \%\right)$, and BG-T $(n=7$, $\delta^{13} \mathrm{C}< \pm 0.11 \%$, $\delta^{15} \mathrm{~N}< \pm 0.38 \%$ ) in the second validation. Some of the organic carbon fractions extracted after $\mathrm{HCl}$ pretreatment were analyzed to obtain radiocarbon age data, corrected for the $\delta^{13} \mathrm{C}$ value, using an accelerator mass spectrometer (AMS) at the University of Tokyo, Japan (Yokoyama et al. 2007), or at Beta Analytic Inc., Florida, USA.

\section{DNA-based analyses}

DNA was analyzed in 18 sections ( 0 to 2,2 to 4,4 to 6 , 8 to 10,13 to 14,14 to 16,22 to 24,30 to 32,38 to 40 , 49 to 52,52 to 55,55 to 58,58 to 61,61 to 64,78 to 80 , 95 to 100,115 to 120 , and 135 to $140 \mathrm{~cm}$ ) of the core sample obtained from L. Maruwan; DNA was extracted from a 0.5 to $1.0 \mathrm{~g}$ sample from each section using an UltraClean Soil DNA Isolation Kit (Mobio, Carlsbad,
CA, USA). Polymerase chain reaction (PCR) amplification of the 16S rRNA gene, denaturing gradient gel electrophoresis (DGGE), and sequencing of the resulting DGGE bands were performed as described previously (Muyzer et al. 1996; Takano et al. 2012). The sequences were taxonomically identified with the RDP Classifier from the Ribosomal Database Project-II release 11.

\section{Results \\ Geochemistry, major elemental compositions, and sedimentary facies}

The olive-gray, olive-black, and dark olive-gray laminations in the upper sections of core Mw5S from $\mathrm{L}$. Maruwan are the remains of soft microbial mats. The laminations in the lower sections of the core are largely gray to olive-black (Figure 3a). The distinct laminations represent conditions favorable for preservation (i.e., no bioturbation). Some sediment deformation was observed at depths of 0 to 5,10 , and 50 to $60 \mathrm{~cm}$. The lithological descriptions and the corresponding ${ }^{14} \mathrm{C}$ ages of organic carbon (years BP) are shown in Figure 3b. Geochemical analyses of carbon, nitrogen, sulfur, and major elements were used to identify the sedimentary facies.

Figure 4a shows depth profiles of the concentrations of the major elements and the carbon and nitrogen isotope ratios. Total carbon (TC) and the carbon isotopic composition $\left(\delta^{13} \mathrm{C}\right)$ of bulk organic matter ranged from 0.7 to $3.5 \mathrm{wt} \%$ (mean, $2.6 \pm 0.6 \mathrm{wt} \%$ ) and from $-17.0 \%$ to $-23.6 \%$ (vs. PDB), respectively. Total nitrogen (TN) and the nitrogen isotopic composition $\left(\delta^{15} \mathrm{~N}\right)$ of the bulk organic matter were $<0.48 \mathrm{wt} \%$ (mean, $0.3 \pm 0.1 \mathrm{wt} \%$ ) and from $+2.2 \%$ to $+6.6 \%$ (vs. Air), respectively. Total sulfur (TS) ranged from 0.3 to $1.6 \mathrm{wt} \%$ (mean, $1.0 \pm$ $0.3 \mathrm{wt} \%)$. The profiles show that the increasing trends in carbon and nitrogen with the movement from marine to freshwater facies in L. Skallen and L. Oyako (Takano et al. 2012; Matsumoto et al. 2014) are not observed in L. Maruwan. The sedimentary facies were not distinguishable on the basis of their nitrogen isotopic 
(a) Landscape around L. Maruwan Oike

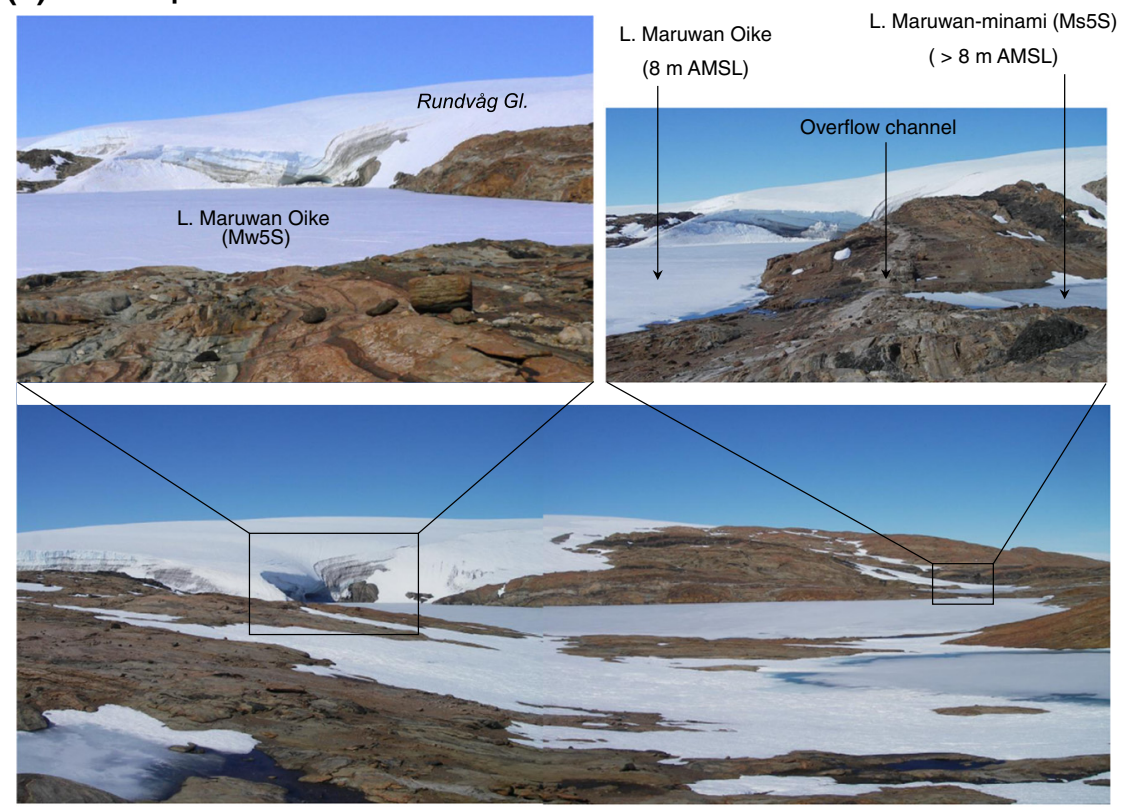

(b) Lateral moraine

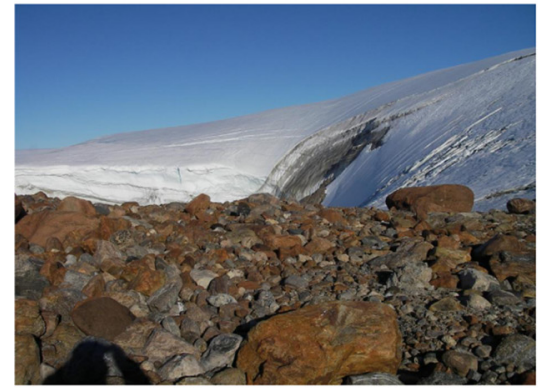

(d) Possible past sub-glacial erosion

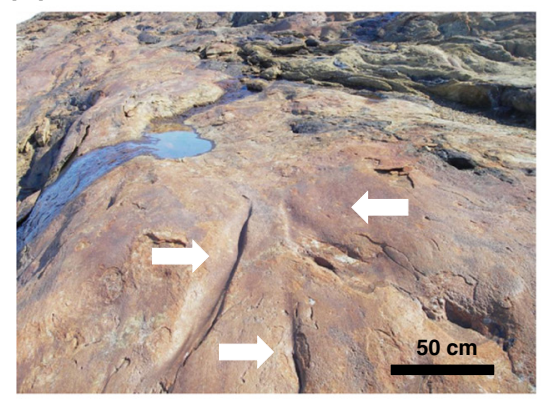

(f) Colored glacial layer in the edge

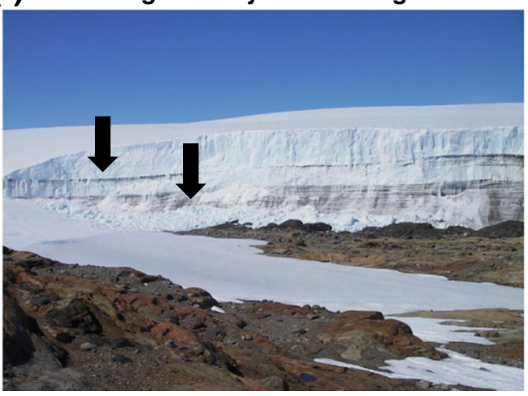

(c) Outflowing from L. Maruwan

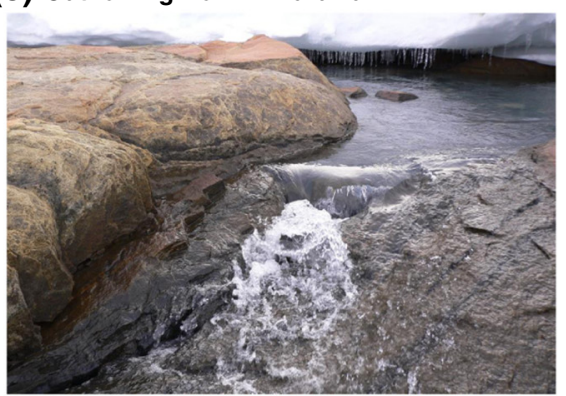

(e) Erratic boulders and modern microbial mat

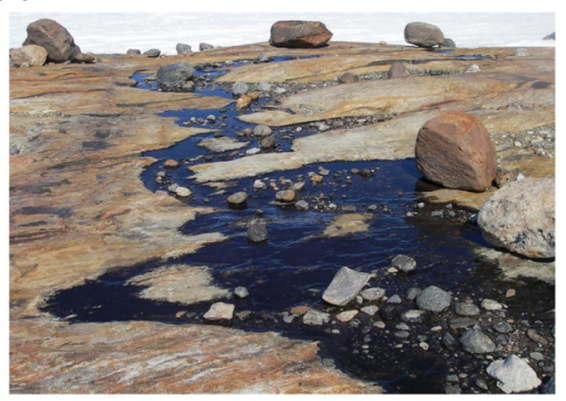

(g) Ice-cave structure beneath the glacier

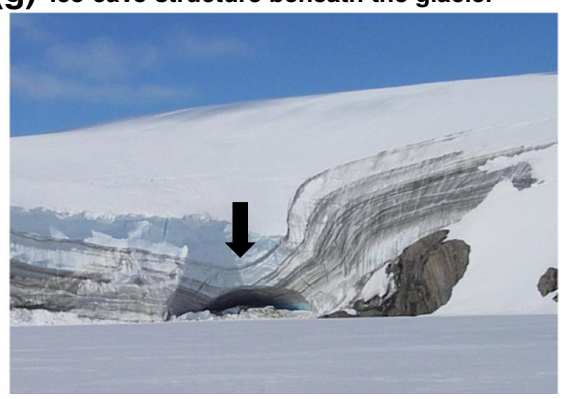

Figure 2 (See legend on next page.) 
(See figure on previous page.)

Figure 2 Terrain in the study area, showing lakes Maruwan, Maruwan-minami, and Maruwan-kita and associated geomorphic features.

The locations of the images are shown by labels a to $\mathrm{g}$ in Figure 1a (lower left panel). (a) Overall features of the study area, showing the proximity of the lakes to Rundvåg Glacier, and the overflow points of lakes Maruwan and Maruwan-minami. (b) Lateral moraine close to Rundvåg Glacier. (c) Outflow of L. Maruwan. (d) Possible subglacial erosion features (after Sawagaki and Hirakawa 1997). (e) Present-day microbial mat (dark area) and erratic boulders transported and deposited by past glaciers. (f) Exposed stratification in glacial ice. (g) Detail of (a), showing a cave-like structure beneath the glacier.

compositions because of the relic nitrogen inputs from subglacial water $\left(\delta^{15} \mathrm{~N}\right.$ up to $+6.6 \%$ in Mw5S; cf. L. Skallen, in the supporting data of Matsumoto et al. 2010).

The trends in the contents of some major elements indicate a marked transition from marine to lacustrine conditions in each of the cores (Figure 4a). The sediments deeper than $50 \mathrm{~cm}$ depth in the Mw5S core were substantially enriched in $\mathrm{SiO}_{2}(<83 \%)$, indicating high $\mathrm{SiO}_{2}$ endmember values under marine conditions and low $\mathrm{SiO}_{2}$ values under freshwater conditions. The mixture of these two end-members can be illustrated on $\mathrm{SiO}_{2}-\mathrm{Al}_{2} \mathrm{O}_{3}$ and $\mathrm{SiO}_{2}-\mathrm{Fe}_{2} \mathrm{O}_{3}$ diagrams, in which contrasting mixing trends are observed (Figure 4b,c). The mixing profiles in these diagrams are similar to those of the reference sample obtained from L. Maruwan-minami (Ms5S; Additional file 1), which is located nearby. The $\mathrm{Al}_{2} \mathrm{O}_{3} / \mathrm{TiO}_{2}$ and $\mathrm{Fe}_{2} \mathrm{O}_{3} / \mathrm{TiO}_{2}$ ratios (Figure $4 \mathrm{~d}$ ) provide information about the source rocks (Young and Nesbitt 1998) episodic hydrological surge events (at 0 to 5 and 50 to $60 \mathrm{~cm}$ ) and subglacial discharge variations (e.g., Brown 2002).

$\mathrm{X}$-ray diffraction analyses of the sediments from core Mw5S indicate that opal-A is abundant throughout the section, except at 0 to $5 \mathrm{~cm}$, suggesting that the silicate is of biogenic origin (Figure 5). To confirm this observation, we also obtained DNA-based molecular evidence of biogenic signatures (see Figure $5 \mathrm{c}$ ). The high endmember $\mathrm{SiO}_{2}$ concentrations, which also suggest large contributions of biogenic silica to the sediments, were probably derived from abundant diatoms (cf. determination of opal-A in the discussion).

\section{Radiocarbon age determinations of sedimentary organic matter}

We determined the AMS radiocarbon $\left({ }^{14} \mathrm{C}\right)$ ages of the organic matter in the core samples (Figure $3 \mathrm{~b}$ and Table 2). The ${ }^{14} \mathrm{C}$ values (years BP) at the top of the core $(1,350 \pm$ 40 years in Mw5S at a depth of 0 to $2 \mathrm{~cm}$ ) indicate significant inputs of relic carbon. Therefore, the sediment age at the top of the core of 1,300 years was subtracted from the raw values to calibrate the radiocarbon dates with the corresponding calendar ages (after Berkman and Forman 1996; Miura et al. 2002). Similarly, marine benthic organisms have yielded ${ }^{14} \mathrm{C}$ ages of $1,010 \pm 110$ to $1,190 \pm 90$ years $\mathrm{BP}$ along the Soya Coast, as reported by Yoshida and Moriwaki (1979). Using this protocol, we estimated the age at which the first sediments were deposited in the bedrock-scoured glacial basin of L. Maruwan (Figures 1 and 4a) to be at least 4,807 to $5,204 \mathrm{cal} \mathrm{BP}(2 \sigma)$. Based on the major elemental compositions (Figure 4b), we also obtained an emergence age (i.e., the transition from marine to freshwater) of 3,382 to $3,560 \mathrm{cal} \mathrm{BP}(2 \sigma)$; the median age of $3,471 \mathrm{cal}$ BP occurs at a depth of 46 to $49 \mathrm{~cm}$. Here, we note the possibility that the period from 4,000 to $1,350 \mathrm{cal} \mathrm{BP}$ represented a hiatus in the sedimentation processes in $\mathrm{L}$. Maruwan. The sedimentary facies in L. Maruwan-minami, in contrast, did not show a similar profile (Additional file 1). Assuming the continuous inflow of subglacial water, the transitions from marine to freshwater conditions via temporary brackish conditions are indistinct in the L. Maruwan cores compared with the transitions observed at lakes Skallen and Oyako, also located on the Soya Coast (Takano et al. 2012).

\section{Preliminary results for biological facies and molecular signatures from DGGE analysis}

A PCR-DGGE analysis was performed to assess the shifts in the composition of residual DNA in the sediments of L. Maruwan (Figure 5c). Depth-related changes were apparent in regions shallower than $6 \mathrm{~cm}$. In the layers deeper than $4 \mathrm{~cm}$, two predominant bands (labeled with arrows in Figure $5 \mathrm{c}$ ) were consistently observed throughout the range analyzed. The nucleotide sequences of the two bands were identical, corresponding to the chloroplasts of the marine diatom Chaetoceros, and were also identical to the diatom sequence detected in the deeper sediment layers of L. Skallen (Takano et al. 2012). The other sequenced DGGE bands (labeled with triangles in Figure 5c) represented taxa of nonphototrophic bacteria determined with a $16 \mathrm{~S}$ rRNA analysis (unpublished data).

\section{Discussion}

\section{Primary producers and estimates of biogenic silica}

The lake sediments in core Mw5S (L. Maruwan) record a continuous input of relic carbon, nitrogen, and bioavailable silica from subglacial water, indicated by their chemical constituents, including major elements and isotopes. Hodson et al. (2010) experimentally verified the chemical weathering and solute production processes in Antarctic glacial meltwater based on aspects of water-rock interactions and hydrochemistry. Stumpf et al. (2012) and Tranter et al. (2005) also suggested the important influence of subglacial weathering on glacial meltwater chemistry, and the potential 
Table 1 Concentrations of major elements (average values of duplicate analyses), TC, TN, and TS in core Mw5S from L. Maruwan

\begin{tabular}{|c|c|c|c|c|c|c|c|c|c|c|c|c|c|c|c|c|c|}
\hline $\begin{array}{l}\text { Depth } \\
(\mathrm{cm})\end{array}$ & Mid-depth & $\begin{array}{l}\text { MgO } \\
\text { (wt\%) }\end{array}$ & $\mathrm{Al}_{2} \mathrm{O}_{3}$ & $\mathrm{SiO}_{2}$ & $\mathrm{~K}_{2} \mathrm{O}$ & $\mathrm{CaO}$ & $\mathrm{TiO}_{2}$ & $\mathrm{MnO}$ & $\mathrm{Fe}_{2} \mathrm{O}_{3}$ & $\begin{array}{l}\text { Carbon } \\
\text { (wt\%) }\end{array}$ & Nitrogen & Sulfur & $\mathrm{C} / \mathrm{N}$ & $\begin{array}{l}{ }^{14} \mathrm{C} \text { age } \\
\text { (years BP) }\end{array}$ & $1 \sigma$ & $\begin{array}{l}\delta^{13} \mathrm{C} \\
\text { (\%o vs. PDB) }\end{array}$ & $\begin{array}{l}\delta^{15} \mathrm{~N} \\
\text { (\%o vs. Air) } \\
\end{array}$ \\
\hline 0 to 2 & 1.0 & 3.0 & 10.5 & 46.6 & 3.4 & 2.8 & 0.91 & 0.17 & 7.5 & 1.3 & 0.00 & 0.3 & - & 1,350 & 40 & -18.0 & $+6.6(n=2)$ \\
\hline 2 to 4 & 3.0 & 2.4 & 9.1 & 53.4 & 2.9 & 2.8 & 0.78 & 0.11 & 6.5 & 1.6 & 0.00 & & - & & & & \\
\hline 4 to 6 & 5.0 & 0.5 & 4.1 & 67.6 & 1.6 & 2.1 & 0.35 & 0.05 & 3.9 & 2.5 & 0.30 & 1.2 & 8.5 & & & & $+4.3(n=2)$ \\
\hline 6 to 8 & 7.0 & 0.0 & 3.2 & 67.2 & 1.4 & 1.9 & 0.30 & 0.05 & 3.7 & 2.8 & 0.36 & & 7.9 & 3,950 & 30 & -21.6 & +3.1 \\
\hline 8 to 10 & 9.0 & 0.7 & 5.9 & 59.3 & 2.2 & 2.5 & 0.50 & 0.07 & 5.0 & 2.3 & 0.27 & 1.6 & 8.7 & & & & \\
\hline 10 to 12 & 11.0 & 1.8 & 6.9 & 58.9 & 2.2 & 2.7 & 0.50 & 0.07 & 4.8 & 2.0 & 0.24 & & 8.3 & 4,200 & 30 & $-20.8(n=2)$ & $+4.9(n=2)$ \\
\hline 12 to 13 & 12.5 & 1.4 & 6.2 & 60.7 & 1.9 & 2.6 & 0.43 & 0.07 & 4.3 & 1.9 & 0.23 & 1.2 & 8.1 & & & & \\
\hline 13 to 14 & 13.5 & 1.3 & 5.4 & 63.7 & 1.7 & 2.4 & 0.39 & 0.06 & 4.0 & 2.0 & 0.26 & & 7.5 & & & & \\
\hline 14 to 16 & 15.0 & 1.7 & 7.0 & 58.3 & 1.9 & 2.9 & 0.45 & 0.07 & 4.8 & 0.7 & 0.00 & 1.1 & - & & & -19.3 & +5.9 \\
\hline 16 to 18 & 17.0 & 0.0 & 2.0 & 67.2 & 1.0 & 1.8 & 0.21 & 0.04 & 3.0 & 2.3 & 0.27 & & 8.7 & & & & \\
\hline 18 to 20 & 19.0 & 0.0 & 2.1 & 74.4 & 1.1 & 1.9 & 0.24 & 0.04 & 3.2 & 2.4 & 0.30 & 1.0 & 8.1 & 3,920 & 40 & -23.6 & +3.2 \\
\hline 20 to 22 & 21.0 & 0.1 & 1.9 & 74.6 & 1.1 & 1.8 & 0.23 & 0.04 & 3.3 & 2.8 & 0.35 & & 8.0 & & & & \\
\hline 22 to 24 & 23.0 & 0.3 & 3.8 & 65.8 & 1.5 & 2.1 & 0.31 & 0.05 & 3.9 & 3.1 & 0.37 & 1.5 & 8.5 & & & & \\
\hline 24 to 26 & 25.0 & 0.3 & 3.6 & 66.6 & 1.5 & 2.1 & 0.31 & 0.05 & 3.6 & 2.2 & 0.24 & & 9.2 & 4,410 & 30 & -20.5 & +2.2 \\
\hline 26 to 28 & 27.0 & 0.2 & 3.3 & 70.9 & 1.4 & 2.0 & 0.29 & 0.05 & 3.6 & 3.2 & 0.38 & 1.3 & 8.3 & & & & \\
\hline 28 to 30 & 29.0 & 0.0 & 1.4 & 74.7 & 0.9 & 1.6 & 0.22 & 0.04 & 2.6 & 3.0 & 0.36 & & 8.2 & & & -21.0 & +4.3 \\
\hline 30 to 32 & 31.0 & 0.0 & 0.9 & 67.3 & 0.7 & 1.5 & 0.13 & 0.05 & 2.8 & 2.7 & 0.35 & 1.1 & 7.8 & & & & \\
\hline 32 to 34 & 33.0 & 0.0 & 3.0 & 64.6 & 1.3 & 2.0 & 0.30 & 0.06 & 3.7 & 2.4 & 0.30 & & 8.0 & 4,630 & 30 & -21.0 & +4.8 \\
\hline 34 to 36 & 35.0 & 0.0 & 3.9 & 65.8 & 1.6 & 2.1 & 0.32 & 0.06 & 3.8 & 2.6 & 0.36 & 1.5 & 7.1 & & & -20.9 & +5.1 \\
\hline 36 to 38 & 37.0 & 0.0 & 2.8 & 69.6 & 1.3 & 2.0 & 0.28 & 0.05 & 3.8 & 3.0 & 0.39 & & 7.6 & & & & \\
\hline 38 to 40 & 39.0 & 0.1 & 3.1 & 71.9 & 1.3 & 2.0 & 0.30 & 0.05 & 3.7 & 2.4 & 0.32 & 1.1 & 7.5 & & & & \\
\hline 40 to 43 & 41.5 & 0.0 & 2.6 & 73.4 & 1.2 & 1.9 & 0.26 & 0.04 & 3.3 & 2.9 & 0.40 & & 7.2 & & & -20.4 & $+4.2(n=2)$ \\
\hline 43 to 46 & 44.5 & 0.0 & 2.7 & 60.8 & 1.2 & 1.9 & 0.23 & 0.04 & 2.8 & 2.6 & 0.36 & 1.3 & 7.1 & & & & \\
\hline 46 to 49 & 47.5 & 0.6 & 4.4 & 65.6 & 1.7 & 2.1 & 0.37 & 0.06 & 3.6 & 3.5 & 0.43 & & 8.0 & 4,540 & 40 & & \\
\hline 49 to 52 & 50.5 & 1.0 & 6.1 & 62.6 & 2.0 & 2.3 & 0.46 & 0.06 & 4.0 & 2.7 & 0.31 & 1.0 & 8.8 & & & -21.2 & +5.8 \\
\hline 52 to 55 & 53.5 & 1.1 & 6.8 & 59.0 & 2.2 & 2.5 & 0.51 & 0.07 & 4.2 & 2.3 & 0.28 & & 8.1 & & & & \\
\hline 55 to 58 & 56.5 & 2.6 & 8.3 & 55.2 & 2.6 & 2.7 & 0.64 & 0.08 & 4.6 & 1.9 & 0.22 & 0.8 & 8.7 & & & & \\
\hline 58 to 61 & 59.5 & 1.8 & 8.1 & 55.6 & 2.6 & 2.7 & 0.62 & 0.08 & 4.5 & 2.4 & 0.24 & & 9.9 & & & -21.1 & +5.7 \\
\hline 61 to 64 & 62.5 & 0.2 & 3.3 & 72.0 & 1.3 & 1.9 & 0.27 & 0.05 & 2.9 & 2.8 & 0.36 & 0.9 & 7.9 & & & & \\
\hline 64 to 67 & 65.5 & 0.0 & 1.3 & 76.4 & 0.9 & 1.6 & 0.17 & 0.04 & 2.8 & 3.1 & 0.43 & & 7.3 & & & & \\
\hline 67 to 70 & 68.5 & 0.0 & 1.5 & 76.4 & 0.9 & 1.7 & 0.18 & 0.04 & 2.8 & 3.0 & 0.40 & 1.1 & 7.6 & & & -21.2 & +5.4 \\
\hline
\end{tabular}


Table 1 Concentrations of major elements (average values of duplicate analyses), TC, TN, and TS in core Mw5S from L. Maruwan (Continued)

\begin{tabular}{|c|c|c|c|c|c|c|c|c|c|c|c|c|c|c|c|c|c|}
\hline 70 to 75 & 72.5 & 0.0 & 0.7 & 79.0 & 0.7 & 1.5 & 0.14 & 0.03 & 2.1 & 3.8 & 0.50 & & 7.7 & 5,220 & 40 & & \\
\hline 75 to 80 & 77.5 & 0.0 & 0.5 & 78.5 & 0.6 & 1.5 & 0.12 & 0.03 & 2.0 & 2.8 & 0.34 & 0.7 & 8.4 & & & & \\
\hline 80 to 85 & 82.5 & 0.0 & 0.4 & 80.9 & 0.6 & 1.4 & 0.10 & 0.03 & 1.7 & 3.3 & 0.48 & & 6.9 & & & -20.6 & +4.9 \\
\hline 85 to 90 & 87.5 & 0.0 & 0.0 & 83.2 & 0.4 & 1.4 & 0.07 & 0.02 & 1.4 & 3.1 & 0.38 & 0.6 & 8.2 & & & & \\
\hline 90 to 95 & 92.5 & 0.0 & 0.3 & 82.1 & 0.5 & 1.4 & 0.09 & 0.02 & 1.6 & 2.9 & 0.35 & & 8.3 & 5,520 & 90 & -21.2 & \\
\hline 95 to 100 & 97.5 & 0.0 & 0.2 & 80.9 & 0.6 & 1.5 & 0.11 & 0.03 & 1.7 & 3.1 & 0.37 & 0.7 & 8.3 & & & -21.8 & +4.5 \\
\hline 100 to 105 & 102.5 & 0.0 & 1.0 & 77.4 & 0.8 & 1.6 & 0.15 & 0.03 & 2.2 & 3.1 & 0.39 & & 7.8 & & & & \\
\hline 105 to 110 & 107.5 & 0.0 & 0.8 & 78.5 & 0.8 & 1.6 & 0.14 & 0.03 & 2.0 & 2.8 & 0.35 & 0.8 & 7.9 & 5,400 & 30 & -20.9 & \\
\hline 110 to 115 & 112.5 & 0.0 & 0.3 & 79.4 & 0.7 & 1.6 & 0.12 & 0.03 & 2.0 & 3.2 & 0.40 & & 8.0 & & & & \\
\hline 115 to 120 & 117.5 & 0.0 & 0.4 & 80.6 & 0.6 & 1.5 & 0.11 & 0.03 & 1.7 & 3.0 & 0.40 & 0.8 & 7.6 & & & -20.9 & +4.2 \\
\hline 120 to 125 & 122.5 & 0.0 & 0.6 & 80.7 & 0.6 & 1.4 & 0.11 & 0.02 & 1.6 & 3.3 & 0.44 & & 7.5 & & & & \\
\hline 125 to 130 & 127.5 & 0.0 & 0.3 & 81.7 & 0.5 & 1.4 & 0.10 & 0.02 & 1.4 & 3.1 & 0.42 & 0.7 & 7.4 & 5,350 & 40 & -17.0 & +2.4 \\
\hline 130 to 135 & 132.5 & 0.0 & 1.7 & 75.3 & 0.9 & 1.7 & 0.18 & 0.04 & 2.3 & 2.6 & 0.32 & & 8.2 & & & & \\
\hline 135 to 140 & 137.5 & 0.0 & 1.7 & 76.0 & 0.9 & 1.7 & 0.18 & 0.03 & 2.3 & 2.7 & 0.34 & 0.9 & 7.9 & & & & \\
\hline 140 to 145 & 142.5 & 0.0 & 1.0 & 79.1 & 0.7 & 1.6 & 0.13 & 0.03 & 1.9 & 2.8 & 0.38 & & 7.3 & & & & \\
\hline 145 to 150 & 147.5 & 0.0 & 1.2 & 77.7 & 0.9 & 1.8 & 0.17 & 0.04 & 2.4 & 2.4 & 0.31 & 0.8 & 7.8 & & & & \\
\hline 150 to 156 & 153.0 & 0.0 & 0.6 & 79.8 & 0.7 & 1.6 & 0.12 & 0.03 & 1.8 & 2.7 & 0.33 & & 8.3 & 6,010 & 70 & $-21.4(n=2)$ & +4.5 \\
\hline
\end{tabular}

Radiocarbon $\left({ }^{14} \mathrm{C}\right.$ age), carbon, and nitrogen isotopic compositions at corresponding depths are also shown. 


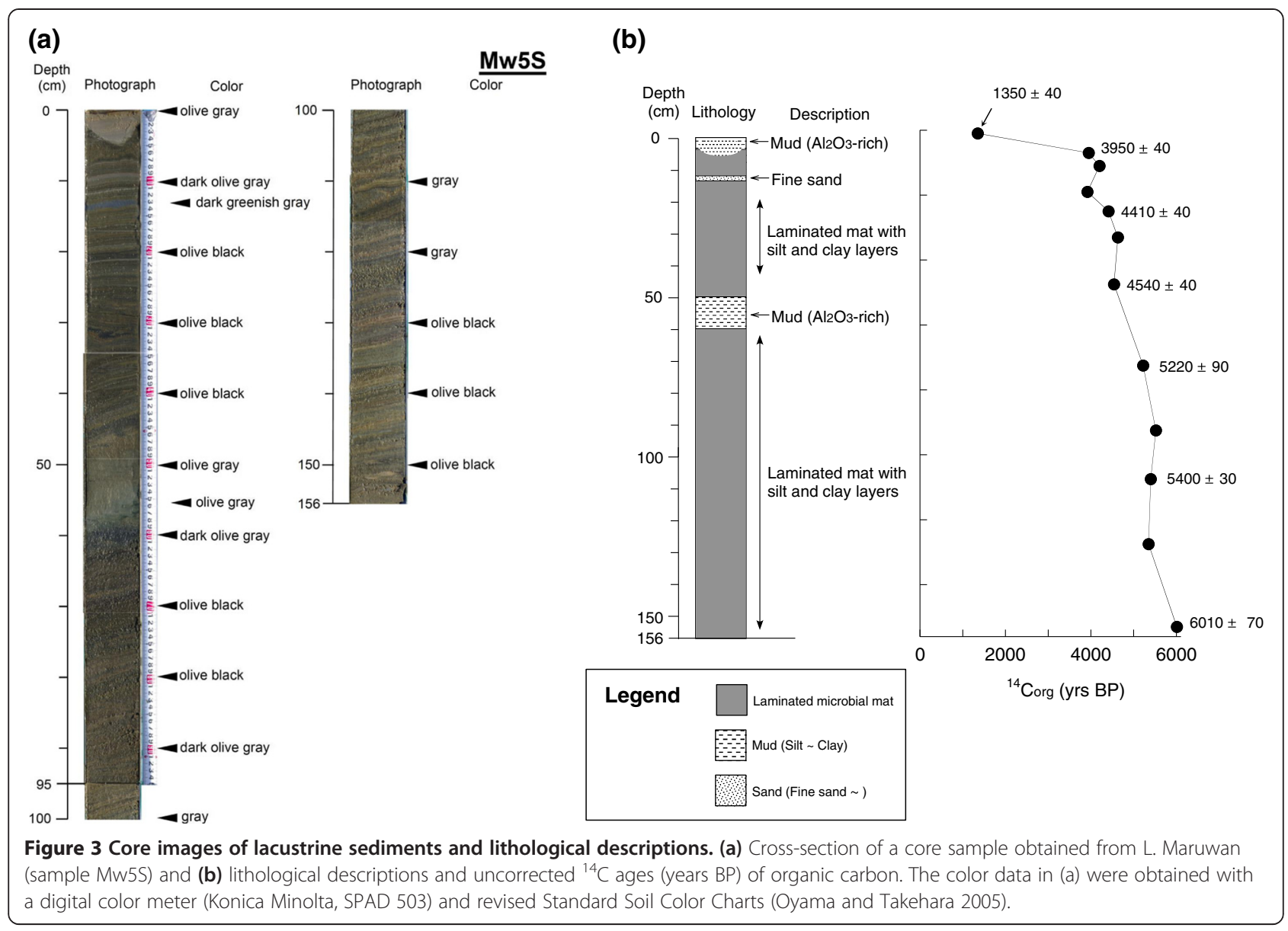

roles of meltwater constituents as sources of energy (e.g., organic carbon) and nutrients (e.g., nitrogen, sulfur, and phosphorus). The concentration of bulk sulfur was also significant in the freshwater sedimentary stage (Figure 4). Using a functional gene marker, Watanabe et al. (2013) pointed out the importance of sulfur cycling and microbial interactions in freshwater environments, including in the modern sediments of L. Maruwan. With respect to the input from physical weathering, clay-sized particles of aluminosilicate minerals are generated by subglacial abrasion processes. These solid-phase materials are transported as suspended sediments into the lake, where they liberate dissolved silica, which can be utilized by diatoms (Figure 6).

With respect to the input from chemical weathering, the simple weathering of rock minerals, including hydrolysis processes involving carbonates, silicates, and aluminosilicates, probably control the composition of the inputs (cf. chemical models: Raiswell 1984). These processes include the following:

$$
\begin{aligned}
& \mathrm{CaCO}_{3}(\mathrm{~s})+\mathrm{H}^{+}(\mathrm{aq}) \rightarrow \mathrm{Ca}^{2+}(\mathrm{aq})+\mathrm{HCO}_{3}^{-}(\mathrm{aq}) \\
& \mathrm{Mg}_{2} \mathrm{SiO}_{4}(\mathrm{~s})+4 \mathrm{H}^{+}(\mathrm{aq}) \rightarrow 2 \mathrm{Mg}^{2+}(\mathrm{aq})+\mathrm{H}_{4} \mathrm{SiO}_{4}(\mathrm{aq})
\end{aligned}
$$

$2 \mathrm{NaAlSi}_{3} \mathrm{O}_{8}(\mathrm{~s})+2 \mathrm{H}^{+}(\mathrm{aq})+9 \mathrm{H}_{2} \mathrm{O} \rightarrow 2 \mathrm{Na}^{+}(\mathrm{aq})+$ $4 \mathrm{H}_{4} \mathrm{SiO}_{4}(\mathrm{aq})+\mathrm{Al}_{2} \mathrm{Si}_{2} \mathrm{O}_{5}(\mathrm{OH})_{4}(\mathrm{~s})$

where $\mathrm{CaCO}_{3}(\mathrm{~s}), \mathrm{Mg}_{2} \mathrm{SiO}_{4}(\mathrm{~s})$, and $\mathrm{NaAlSi}_{3} \mathrm{O}_{8}(\mathrm{~s})$ denote calcite, forsterite, and albite, respectively. We observed increasing trends in the concentrations of $\mathrm{CaO}, \mathrm{MgO}$, and $\mathrm{K}_{2} \mathrm{O}$ in the lacustrine facies after the marinefreshwater transition (Figure 4). The water-rock interactions involving forsterite (Satish-Kumar and Wada 2000) and albite (cf. Shiraishi et al. 1987) in the Lützow-Holm complex will eventually produce dissolved silica as $\mathrm{H}_{4} \mathrm{SiO}_{4}$ (aq) and a clay mineral (kaolinite) as $\mathrm{Al}_{2} \mathrm{Si}_{2} \mathrm{O}_{5}$ $(\mathrm{OH})_{4}(\mathrm{~s})$, respectively. It is particularly relevant that the dissolved silica is biologically available as an essential nutrient and growth element for diatoms.

Because biogenic opal-A is a major component of the L. Maruwan sediments, we were able to estimate the concentrations of biogenic silica in the sediment. We calculated the flux of biogenic silica in core Mw5S based on the end-member $\mathrm{SiO}_{2}$ and $\mathrm{Al}_{2} \mathrm{O}_{3}$ concentrations, assuming that: (i) $\mathrm{Al}$ is only contained in the detrital component (of glacial inorganic origin) because $\mathrm{Al}_{2} \mathrm{O}_{3}$ 
(a) L. Maruwan (Mw5S)
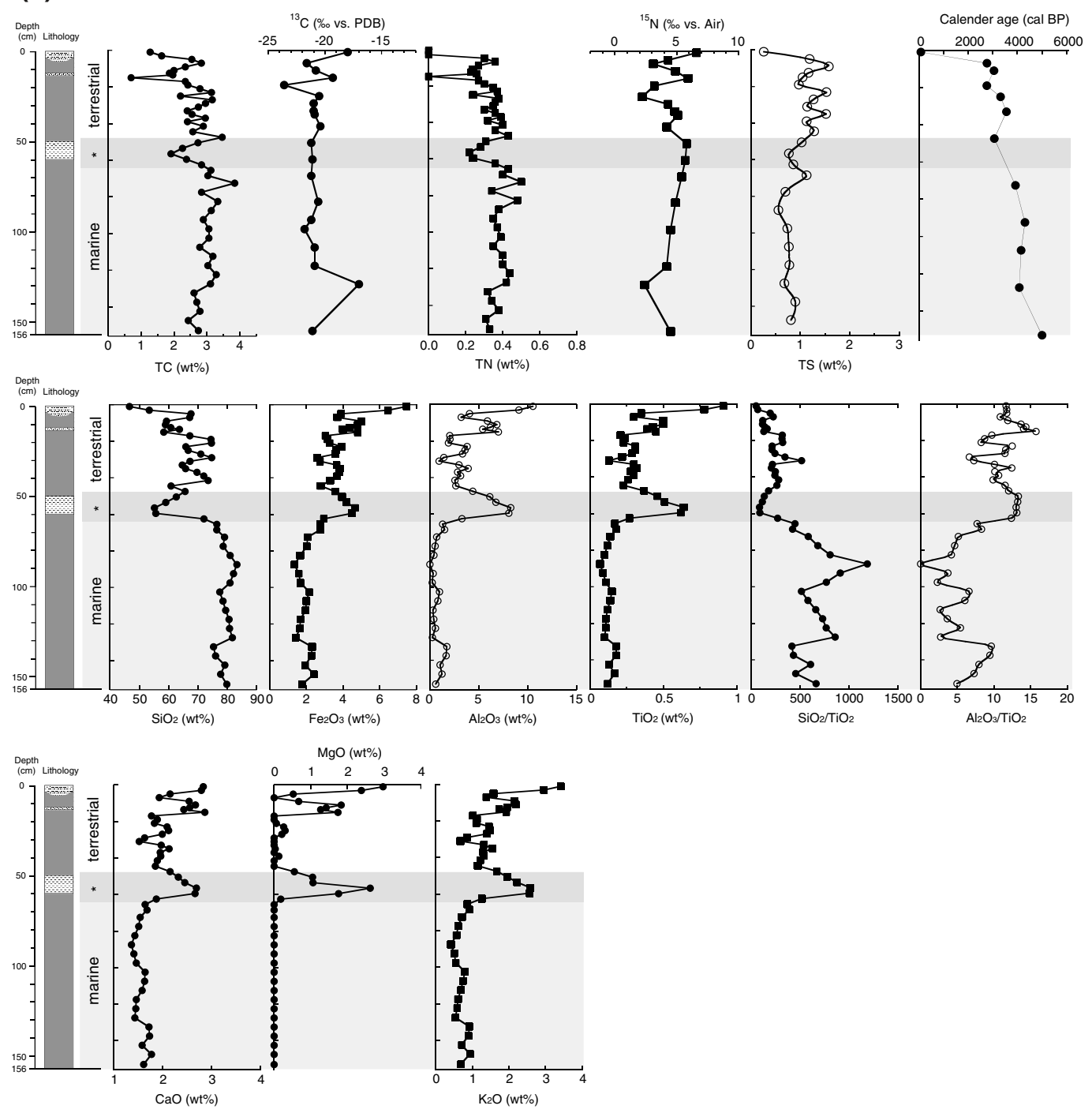

(b) L. Maruwan (Mw5S)

(c) L. Maruwan-minami (Ms5S)

(d) Similarity of sedimentary source
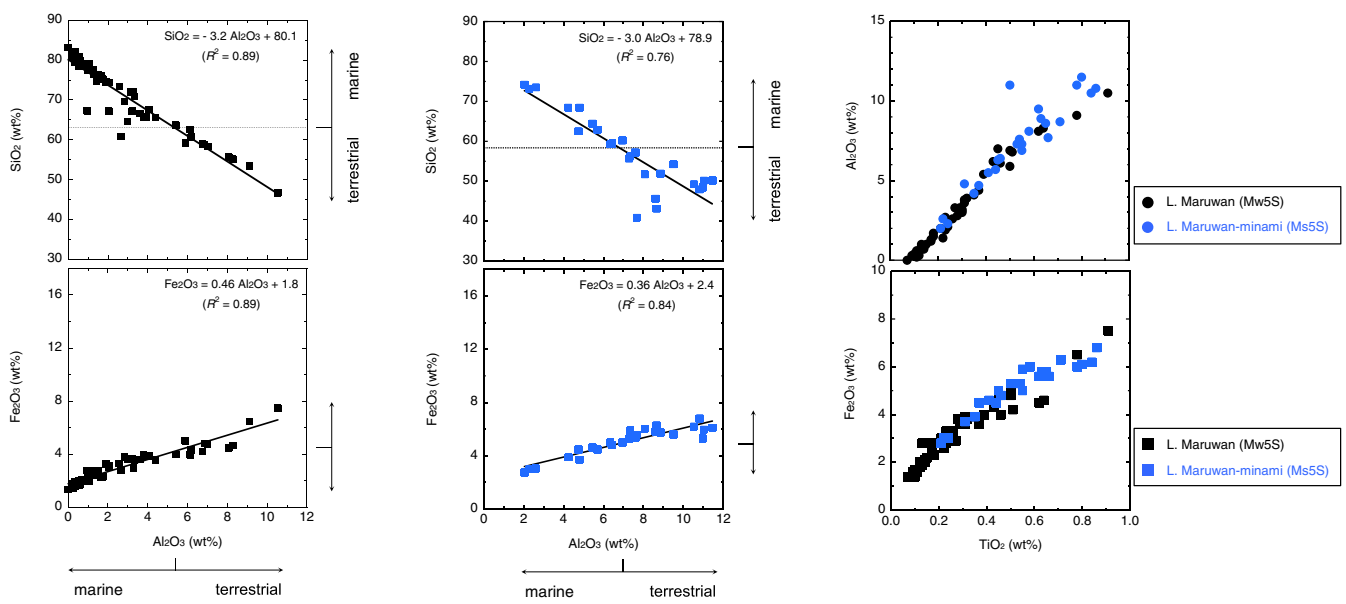

Figure 4 (See legend on next page.) 
(See figure on previous page.)

Figure 4 Vertical profiles of some major elements, $\mathrm{SiO}_{2}-\mathrm{Al}_{2} \mathrm{O}_{3}$ and $\mathrm{SiO}_{2}-\mathrm{Fe}_{2} \mathrm{O}_{3}$ diagrams, bivariate $\mathrm{TiO}_{2}-\mathrm{Al}_{2} \mathrm{O}_{3}$ and $\mathrm{TiO}_{2}-\mathrm{Fe}_{2} \mathrm{O}_{3}$ plots. (a) Vertical profiles of lithologies, total carbon (TC), $\delta^{13} \mathrm{C}_{\text {org }}$ (\%o vs PDB), total nitrogen (TN), $\delta^{15} \mathrm{~N}$ (\% vs air), total sulfur (TS), ${ }^{14} \mathrm{C}$ ages, wt $\%$ of major elements $\left(\mathrm{SiO}_{2}, \mathrm{Fe}_{2} \mathrm{O}_{3}, \mathrm{Al}_{2} \mathrm{O}_{3}, \mathrm{TiO}_{2}, \mathrm{CaO}, \mathrm{MgO}, \mathrm{K}_{2} \mathrm{O}\right)$, and major elemental ratios $\left(\mathrm{SiO}_{2} / \mathrm{TiO}_{2}\right.$ and $\left.\mathrm{Al}_{2} \mathrm{O}_{3} / \mathrm{TiO}_{2}\right)$ in core Mw5S from L. Maruwan, showing the transition between the marine and terrestrial stages via possible brackish conditions (*based on microflora differences at a depth of $60 \mathrm{~cm}$, determined with a DGGE analysis). The raw data are provided in Table 1. (b), (c) $\mathrm{Al}_{2} \mathrm{O}_{3}-\mathrm{SiO}_{2}$ and $\mathrm{Al}_{2} \mathrm{O}_{3}-\mathrm{Fe}_{2} \mathrm{O}_{3}$ diagrams for $\mathrm{L}$. Maruwan (core Mw5S) and Maruwan-minami (core Ms5S) sediments. Possible end-members of marine and terrestrial major elements are noted on the axes. (d) The similarity of the source rocks of $\mathrm{L}$. Maruwan (core Mw5S, black symbols: $R^{2}=0.97$ and 0.92 ) and L. Maruwan-minami (core Ms5S, blue symbols: $R^{2}=0.85$ and 0.89 ) was confirmed with bivariate $\mathrm{TiO}_{2}-\mathrm{Al}_{2} \mathrm{O}_{3}$ and $\mathrm{TiO}_{2}-\mathrm{Fe}_{2} \mathrm{O}_{3}$ plots.

concentrations are constant throughout the core at $10.5 \%$ (representing the freshwater end-member) and (ii) $\mathrm{SiO}_{2}$ is contained in both the biogenic and detrital components (of glacial inorganic origin), with $\mathrm{SiO}_{2}$ concentrations in the detritus constant at $46.6 \%$ (representing the freshwater end-member). Therefore,

$$
\begin{aligned}
\text { Total silica }(\%)= & \text { Biogenic silica }(\%) \\
& + \text { Detrital silica }(\%)
\end{aligned}
$$

where the detrital ratio of the end-member (Figure 4b,c) is as follows:

$$
\begin{aligned}
& \text { Detrital silica(\%)/Detrital } \mathrm{Al}_{2} \mathrm{O}_{3}(\%) \\
& \quad=46.6(\%) / 10.5(\%)
\end{aligned}
$$

Hence, for L. Maruwan:

Biogenic silica $(\%)=$ Total silica $(\%)-4.43$ Detrital $\mathrm{Al}_{2} \mathrm{O}_{3}(\%)$ and in L. Maruwan-minami:

$$
\text { Biogenic silica }(\%)=\text { Total silica }(\%)-4.36 \text { Detrital } \mathrm{Al}_{2} \mathrm{O}_{3}(\%)
$$

Based on the $\mathrm{TiO}_{2}$-normalized plots of $\mathrm{Al}_{2} \mathrm{O}_{3}$ and $\mathrm{Fe}_{2} \mathrm{O}_{3}$, the similarity of the source rocks in the two lakes is high (Figure 4d), suggesting the discharge of homogenous meltwater into both lakes.

Figure 5a shows the depth profiles of the reconstructed biogenic silica concentrations in L. Maruwan. After the marine-terrestrial transition, diatoms were the main primary producers, even in the freshwater/brackish environments. Based on the DGGE and molecular analyses, the major phototrophic producers were identical to those detected in the deeper sediment layers of $\mathrm{L}$. Skallen (i.e., diatoms) (Takano et al. 2012). Therefore, the origin of $\mathrm{Si}$ in the Antarctic lakes is of particular interest because dissolved silica is essential for the growth of diatoms (i.e., diatoms are the dominant group of phytoplankton with amorphous opal constituents).

\section{(a)}

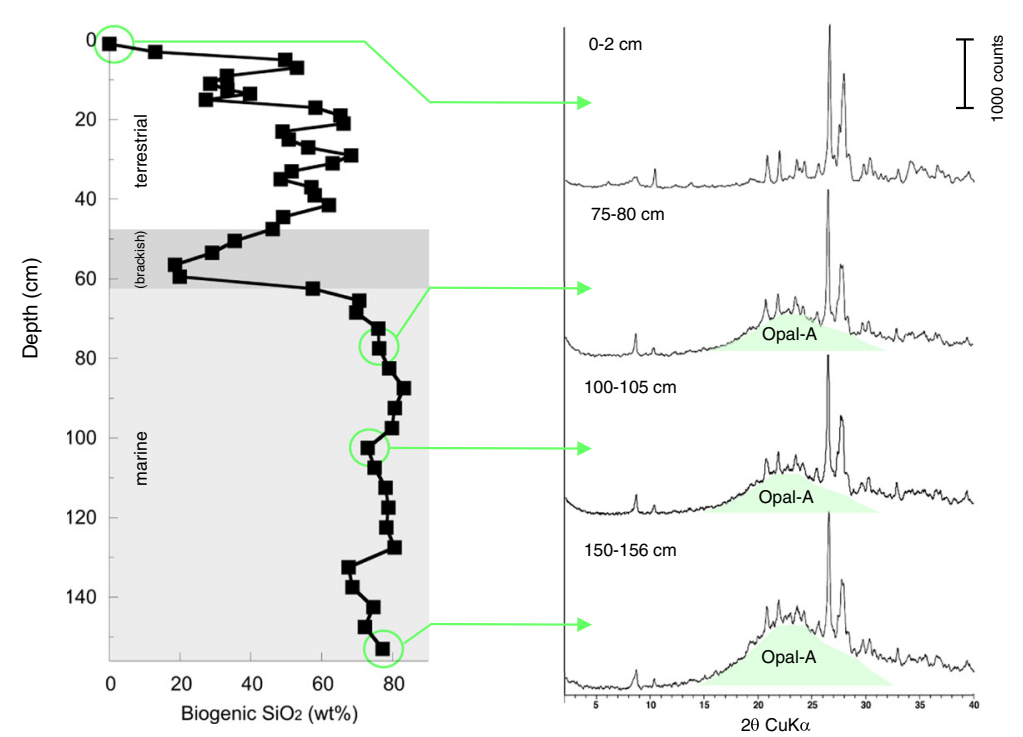

(c)

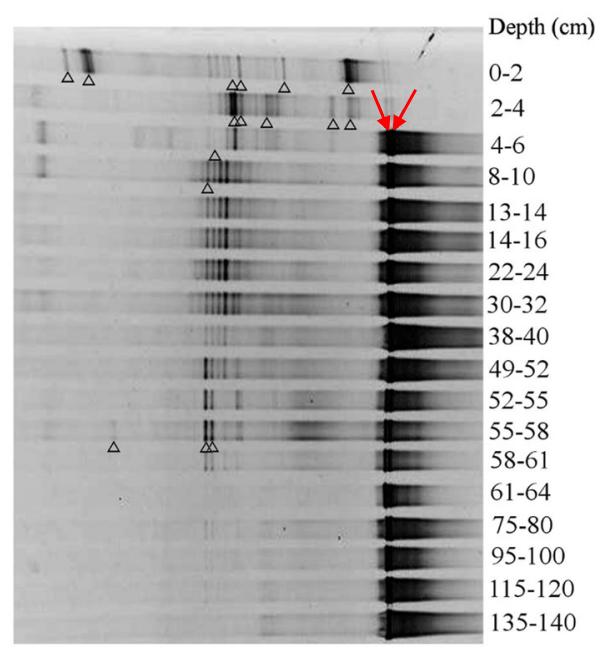

Figure 5 Depth profiles of biogenic silica concentrations and X-ray diffraction analyses of sediments from core Mw5S. (a) Vertical profiles of biogenic silica content (wt\%), (b) opal-A signatures determined with X-ray diffraction analysis, and (c) denaturing gradient-gel electrophoresis (DGGE) analysis of L. Maruwan sediments (core Mw5S). Note that the direction of electrophoresis is from right to left. 
Table 2 Radiocarbon $\left({ }^{14} \mathrm{C}\right)$ age data obtained with AMS for the organic carbon fractions from core Mw5S from L. Maruwan

\begin{tabular}{|c|c|c|c|c|c|}
\hline $\begin{array}{l}\text { Depth } \\
\text { (cm) } \\
\end{array}$ & Mid-depth & $\begin{array}{l}\text { Conventional radiocarbon } \\
\text { age }\left(\delta^{13} C \text { corrected) }\right. \\
\text { (years BP) }\end{array}$ & $\begin{array}{l}1 \sigma \\
\pm \\
\end{array}$ & $\begin{array}{l}\text { Calendar age ( } 2 \sigma \text { range) } \\
\text { (cal BP) }\end{array}$ & $\begin{array}{l}\text { Relative area under } \\
\text { probability function }\end{array}$ \\
\hline \multirow[t]{2}{*}{0 to 2} & 1.0 & 1,350 & 40 & 24 to 141 & 0.73 \\
\hline & & & & 220 to 262 & 0.25 \\
\hline \multirow[t]{2}{*}{6 to 8} & 7.0 & 3,950 & 30 & 2,737 to 2,798 & 0.93 \\
\hline & & & & 2,819 to 2,844 & 0.06 \\
\hline 10 to 12 & 11.0 & 4,200 & 30 & 2,950 to 3,160 & 1.00 \\
\hline \multirow[t]{3}{*}{18 to 20} & 19.0 & 3,920 & 40 & 2,706 to 2,813 & 0.94 \\
\hline & & & & 2,816 to 2,844 & 0.03 \\
\hline & & & & 2,618 to 2,633 & 0.03 \\
\hline 24 to 26 & 25.0 & 4,410 & 30 & 3,256 to 3,392 & 1.00 \\
\hline 32 to 34 & 33.0 & 4,630 & 30 & 3,475 to 3,637 & 1.00 \\
\hline 46 to 49 & 47.5 & 4,540 & 40 & 3,382 to 3,560 & 1.00 \\
\hline 70 to 75 & 72.5 & 5,220 & 40 & 3,790 to 4,053 & 1.00 \\
\hline 90 to 95 & 92.5 & 5,520 & 90 & 4,056 to 4,565 & 1.00 \\
\hline 105 to 110 & 107.5 & 5,400 & 30 & 4,042 to 4,274 & 1.00 \\
\hline 125 to 130 & 127.5 & 5,350 & 40 & 3,950 to 4,218 & 1.00 \\
\hline 150 to 156 & 153.0 & 6,010 & 70 & 4,807 to 5,204 & 1.00 \\
\hline
\end{tabular}

Conventional radiocarbon dating based on organic carbon values $\left({ }^{14} \mathrm{C}_{\text {org }}\right.$, years $\left.\mathrm{BP}\right)$ was corrected for the marine reservoir effect $(\Delta R=1,300$ years for the marine stage sequence) using core-top data. Calendar age data were calculated using the calibration programs Calib Rev 6.0.1 (Stuiver and Reimer 1993; Stuiver et al. 1998), INTCAL09 and MARINE09 (e.g., Hughen et al. 2004; Reimer et al. 2004, 2009). See discussions of the biogeochemical recycling processes for relic carbon in the Antarctic region (e.g., Ingolfsson et al. 1998; Berkman et al. 1998) and the Soya Coast region (e.g., Miura et al. 2002).

\section{Subglacial abrasion and weathering cause continuous input of silica}

Sawagaki and Hirakawa (1997) have described the formation of glacial erosional bedforms in the Rundvågshetta area. The erosional bedforms are accompanied by small erosional marks, which support the interpretation that subglacial meltwater has contributed to the erosion at the base of Antarctic glaciers (cf. Figure 6). It is important to note that some subglacial erosional features may have resulted from subglacial streams, as shown in Figure 2d. Anderson et al. (2002) have extensively reviewed the features of subglacial meltwater drain channels beneath continental ice sheets. Observations and interpretations of these bedforms have been used to reconstruct the historical development of glacial erosional bedforms (e.g., Shaw 2002), and to understand the significance and implications of subglacial water-rock interactions. Further support for this finding comes from the cosmogenic radionuclide dating of local glacial erratics and bedrock (Yamane et al. 2011). Both bedrocks and erratics show similar exposure ages, suggesting the presence of warm basal ice during the last glacial period, which would have included subglacial water channels.

We suggest that the continuous input of subglacial meltwater influenced the chemical compositions of areas marginal to the ice sheet (also, see de Mora et al. 1994;
Brown 2002). Nelson and Treguer (1992) reported that silicon is an important limiting nutrient for Antarctic diatom productivity. Total biogenic silica (\%) and total carbon contents are positively correlated in L. Maruwan ( $R=0.75$; this study). When inferring the past constraints on the primary production by diatoms in the ice-marginal lakes, we concluded that the subglacial weathering of silicate and aluminosilicate minerals supplied significant levels of minerals, nitrogen, and relic carbon to subglacial meltwaters (e.g., Hutchins and Bruland 1998). Therefore, dissolved inorganic silicates are constantly available for utilization by the diatom communities that are the primary producers in the perennially ice-covered lakes at Rundvågshetta.

\section{Conclusions}

[1] This study provides the first published data on the subglacial limnology and Si biogeochemistry of L. Maruwan, Rundvågshetta. The reservoir effects of relic carbon derived from the subglacial water beneath the Rundvåg Glacier were estimated at 1,300 years (cf. core-top age 1,350 years in Mw5S). The nitrogen isotopic composition of the bulk sediment was slightly ${ }^{15} \mathrm{~N}$-enriched relative to the dinitrogen in atmospheric air, even in freshwater 
(a) Past sub-glacial setting

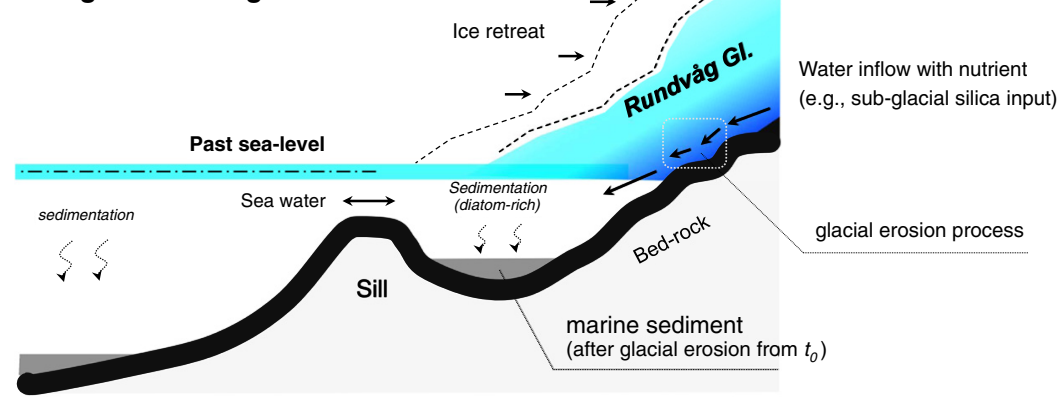

(b) Present lacustrine setting (glacial lake)

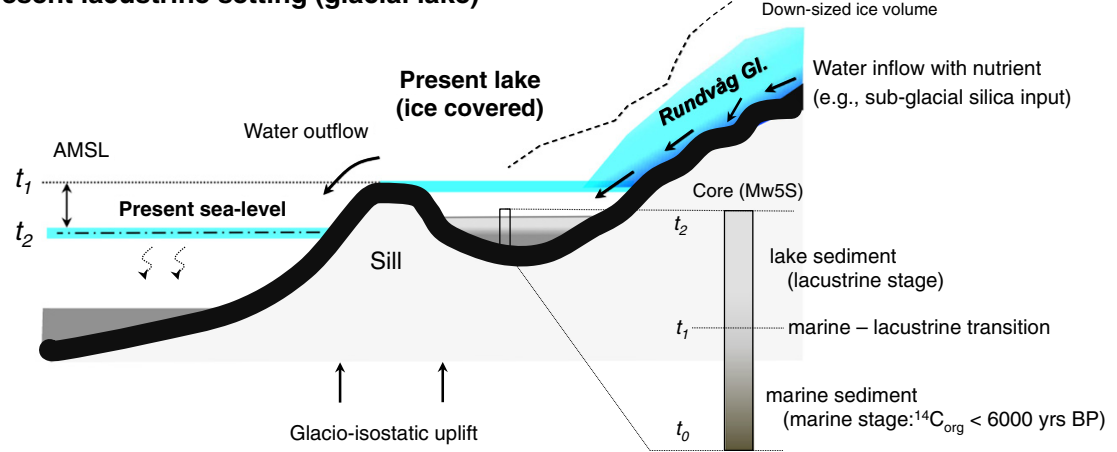

Figure 6 Inflow of subglacial meltwater containing solid-phase materials and dissolved nutrients, including silica, relic carbon, and nitrogen. Schematic models of (a) past lake setting after glacial erosion (i.e., the initiation of sedimentation processes during the marine phase) and (b) present lake setting (lacustrine stage). The relative sea level is controlled by glacio-isostatic uplift. For the present sea ice conditions during the summer season (December 2005; photograph taken from a helicopter), please see the description of the landscape of Rundvågshetta (Additional file 1).

environments (cf. sedimentary $\delta^{15} \mathrm{~N}$ in freshwater at L. Skallen). Based on the similarities in the compositions of their major sedimentary elements, lakes Maruwan and Maruwan-minami share the same meltwater source composition.

[2] We suggest that the amount of bioavailable silica flowing out from subglacial drainage channels under the EAIS and into subglacial and proglacial lakes in the area is extremely limited, underscoring the biological significance of subglacial physicochemical weathering and water-rock interactions. Inorganic Si is the main source of biogenic silica (up to $83 \mathrm{wt} \%$ ) for lacustrine diatom communities, indicating the strong relationship between the subglacial material exported from the glacial system and the primary production in these glacial lakes during the Holocene.

\section{Additional file}

Additional file 1: Supplementary Information. Biogeochemistry and limnology in Antarctic subglacial weathering: Molecular evidence of the linkage between subglacial silica input and primary producers in a perennially ice-covered lake.

\section{Abbreviations}

EAIS: East Antarctic Ice Sheet; WAIS: West Antarctic Ice Sheet; LHB: Lützow-Holm Bay; AMSL: above the mean sea level; opal-A: amorphous hydrated silica; AMS: accelerator mass spectrometry; XRF: X-ray fluorescence; XRD: X-ray diffraction; PCR: polymerase chain reaction; DGGE: denaturing gradient gel electrophoresis.

\section{Competing interests}

The authors declare that they have no competing interests.

\section{Authors' contributions}

YT compiled the geochemical data and wrote the paper. HK and ET contributed to the molecular analysis. YY supported the radiocarbon analysis. YT and MF performed the field investigations and designed the entire research project, in discussion with the coauthors. All authors read and approved the final manuscript.

\section{Authors' information}

YT is a senior research scientist at the Department of Biogeochemistry, Japan Agency for Marine-Earth Science and Technology (JAMSTEC). HK is an assistant professor at the Institute of Low Temperature Science, Hokkaido University. ET was a graduate school student at the Institute of Low Temperature Science, Hokkaido University. YY is a professor at the Atmosphere and Ocean Research Institute (AORI), University of Tokyo. MF is a professor at the Institute of Low-Temperature Science, Hokkaido University.

\section{Acknowledgements}

We thank J. Sickman (Univ. California, Riverside), J. Tyler (Univ. Adelaide), and an anonymous reviewer for critical and constructive comments which helped to improve an earlier version of the manuscript. We also thank $\mathrm{T}$. Sato (Hiroshima Univ.) and S. Imura (Natl. Inst. Polar Res., NIPR) for logistical 
supports, T. Sawagaki (Hokkaido Univ.) for the onsite field guide regarding past glacial erosion processes, N. Suzuki (Hokkaido Univ.) and N. Ohkouchi (JAMSTEC) for discussions, and members of the 47th Japan Antarctica Research Expedition (Expedition Leader: K. Shiraishi, NIPR) for logistical assistance. The AMS experiments were partially supported by Dr. $\mathrm{H}$. Matsuzaki (Univ. Tokyo). Part of this work has been presented at the AGU Chapman Conference 2010 on the Exploration and Study of Antarctic Subglacial Aquatic Environment at Baltimore, USA. This research was supported in part by the Japan Society for the Promotion of Science (Y.T.) and NEXT program No. GR031 (Y.Y).

\section{Author details}

'Department of Biogeochemistry, Japan Agency for Marine-Earth Science and Technology (JAMSTEC), 2-15 Natsushima, Yokosuka, Kanagawa 237-0061, Japan. ${ }^{2}$ The Institute of Low Temperature Science, Hokkaido University, N19, W8, Kita-ku, Sapporo, Hokkaido 060-0819, Japan. ${ }^{3}$ Atmosphere and Ocean Research Institute, University of Tokyo, 5-1-5 Kashiwanoha, Kashiwa, Chiba 277-8564, Japan.

Received: 29 September 2014 Accepted: 17 February 2015 Published online: 15 April 2015

\section{References}

Anderson JB, Shipp SS, Lowe AL, Wellner JS, Mosola AB (2002) The Antarctic ice sheet during the Last Glacial Maximum and its subsequent retreat history: a review. Quaternary Sci Rev 21:49-70

Bassett S, Milne G, Bentley M, Huybrechts P (2007) Modelling Antarctic sea-level data to explore the possibility of a dominant Antarctic contribution to meltwater pulse IA. Quaternary Sci Rev 26:2113-2127

Bentley M, Christoffersen P, Hodgson D, Smith AM, Tulaczyk S, Le Brocq A (2011) Subglacial lake sediments and sedimentary processes: potential archives of ice sheet evolution, past environmental change, and the presence of life. Geophys Monogr Ser 192:83-110

Berkman PA, Forman SL (1996) Pre-bomb radiocarbon and the reservoir correction for calcareous marine species in the Southern Ocean. Geophys Res Lett 23:363-366

Berkman PA, Andrews JT, Bjorck S, Colhoun EA, Emslie SD, Goodwin ID, Hall BL, Hart CP, Hirakawa K, Igarashi A, Ingolfsson O, Lopez-Martinez J, Lyons WB, Mabin MCG, Quilty PG, Taviani M, Yoshida Y (1998) Circum-Antarctic coastal environmental shifts during the Late Quaternary reflected by emerged marine deposits. Antarctic Sci 10:345-362

Brown GH (2002) Glacier meltwater hydrochemistry. Appl Geochem 17:855-883

Christner BC, Royston-Bishop G, Foreman CM, Arnold BR, Tranter M, Welch KA, Lyons WB, Tsapin Al, Studinger M, Priscu JC (2006) Limnological conditions in subglacial Lake Vostok, Antarctica. Limnol Oceanogr 51:2485-2501

Cox R, Culkin F, Riley J (1967) The electrical conductivity/chlorinity relationship in natural sea water. Deep Sea Res Oceanogr Abst 14:203-220

de Mora SJ, Whitehead R, Gregory M (1994) The chemical composition of glacial melt water ponds and streams on the McMurdo Ice Shelf, Antarctica. Antarctic Sci 6:17-27

Esposito R, Horn S, McKnight D, Cox M, Grant M, Spaulding S, Doran P, Cozzetto $\mathrm{K}$ (2006) Antarctic climate cooling and response of diatoms in glacial meltwater streams. Geophys Res Lett 33:L07406

Geographical Survey Institute (1984) Rundvågshetta: the principal part. Map compilation from air photography, controlled by triangulation points established by JARE, 1971 and 1974

Hodgson DA, Verleyen E, Squier AH, Sabbe K, Keely BJ, Saunders KM, Vyverman W (2006) Interglacial environments of coastal east Antarctica: comparison of MIS 1 (Holocene) and MIS 5e (Last Interglacial) lake-sediment records. Quaternary Sci Rev 25:179-197

Hodgson DA, Roberts SJ, Bentley MJ, Smith JA, Johnson JS, Verleyen E, Vyverman W, Hodson AJ, Leng MJ, Cziferszky A, Fox AJ, Sanderson DCW (2009) Exploring former subglacial Hodgson Lake, Antarctica Paper l: site description, geomorphology and limnology. Quaternary Sci Rev 28:2295-2309

Hodson A (2006) c. Water Resource Res 42, W11406. doi:11410.11029/12005WR00431

Hodson A, Heaton T, Langford H, Newsham K (2010) Chemical weathering and solute export by meltwater in a maritime Antarctic glacier basin. Biogeochem 98:9-27

Hughen KA, Baillie MGL, Bard E, Beck JW, Bertrand CJH, Blackwell PG, Buck CE, Burr GS, Cutler KB, Damon PE, Edwards RL, Fairbanks RG, Friedrich M, Guilderson TP, Kromer B, McCormac G, Manning S, Ramsey CB, Reimer PJ, Reimer RW, Remmele S, Southon JR, Stuiver M, Talamo S, Taylor FW, der
Plicht J, Weyhenmeyer CE (2004) Marine04 marine radiocarbon age calibration, 0-26 cal kyr BP. Radiocarbon 46:1059-1086

Hutchins DA, Bruland KW (1998) Iron-limited diatom growth and Si:N uptake ratios in a coastal upwelling regime. Nature 393:561-564

Imai N, Terashima S, Itoh S, Ando A (1995) 1994 compilation values for GSJ reference samples, igneous rock series. Geochem J 29:91-95

Imai N, Terashima S, Itoh S, Ando A (1999) 1998 compilation of analytical data for five GSJ geochemical reference samples. Geostandards Newslett 23:223-250

Imura S, Bando T, Seto K, Ohtani S, Kudoh S, Kanda H (2003) Distribution of aquatic mosses in the Soya Coast region, East Antarctica. Polar Biosci 16:1-10

Ingolfsson O, Hjort C, Berkman PA, Bjorck S, Colhoun E, Goodwin ID, Hall B, Hirakawa K, Melles M, Moller P, Prentice ML (1998) Antarctic glacial history since the Last Glacial Maximum: an overview of the record on land. Antarctic Sci 10:326-344

Jouzel J, Petit J, Souchez R, Barkov N, Lipenkov V, Raynaud D, Stievenard M, Vassiliev N, Verbeke V, Vimeux F (1999) More than 200 meters of lake ice above subglacial Lake Vostok, Antarctica. Science 286:213-2141

Kapitsa A, Ridley J, Robin G, Siegert M, Zotikov I (1996) A large deep freshwater lake beneath the ice of central East Antarctica. Nature 381:684-686

Karl DM, Bird DF, Bjorkman K, Houlihan T, Shackelford R, Tupas L (1999) Microorganisms in the accreted ice of Lake Vostok, Antarctica. Science 286:2144-2147

Kastner M, Keene J, Gieskes J (1977) Diagenesis of siliceous oozes - I. Chemical controls on the rate of opal-A to opal-CT transformation - an experimental study. Geochim Cosmochim Acta 41:1041-1059

Koblinsky C, Hildebrand P, LeVine D, Pellerano F, Chao Y, Wilson W, Yueh S, Lagerloef $G$ (2003) Sea surface salinity from space: science goals and measurement approach. Radio Sci 38:8064, 10.1029/2001RS002584

Kudoh S, Tanabe Y (2014) Limnology and ecology of lakes along the Sôya Coast, East Antarctica. Adv Polar Sci 25:75-91

Lee K, Tong LT, Millero FJ, Sabine CL, Dickson AG, Goyet C, Park GH, Wanninkhof R, Feely RA, Key RM (2006) Global relationships of total alkalinity with salinity and temperature in surface waters of the world's oceans. Geophys Res Lett 33:L19605, 10.1029/2006GL027207

Leng MJ, Barker PA (2006) A review of the oxygen isotope composition of lacustrine diatom silica for palaeoclimate reconstruction. Earth-Sci Rev 75:5-27

Matsumoto G, Tani Y, Seto K, Tazawa T, Yamamuro M, Watanabe T, Nakamura T, Takemura T, Imura S, Kanda H (2010) Holocene paleolimnological changes in Lake Skallen Oike in the Syowa Station area of Antarctica inferred from organic components in a sediment core (Sk4C-02). J Paleolimnol 44:677-693

Matsumoto G, Honda E, Seto K, Tani Y, Watanabe T, Ohtani S, Kashima K, Nakamura T, Imura S (2014) Holocene paleolimnological changes of Lake Oyako-ike in the Soya Kaigan of East Antarctica. Inland Waters 4:105-112

Mikucki JA, Pearson A, Johnston DT, Turchyn AV, Farquhar J, Schrag DP, Anbar AD, Priscu JC, Lee PA (2009) A contemporary microbially maintained subglacial ferrous "Ocean". Science 324:397-400

Miura H, Maemoku H, Igarashi A, Moriwaki K (1998) Late Quaternary raised beach deposits and radiocarbon dates of marine fossils around Lützow-Holm Bay. Special map series of National Institute of Polar Research, pp. 1-46

Miura H, Maemoku H, Moriwaki K (2002) Holocene raised beach stratigraphy and sea-level history at Kizahashi Beach, Skarvsnes, Lutzow-Holm Bay, Antarctica. Royal Soc New Zealand Bull 35:391-396

Murayama H (1977) General characteristics of the Antarctic lakes near Syowa station. Antarctic Record 58:43-62

Muyzer G, Brinkhoff T, Nübel U, Santegoeds C, Schafer H, Wawer C (1996) Denaturing gradient gel electrophoresis (DGGE) in microbial ecology. In: Akkermans ADL, van Elsas JD, de Bruijn FJ (eds) Molecular microbial ecology manual, 3rd edn. Kluwer Academic Publishers, Dordrecht, The Netherlands, pp 1-27, p. 3.4.4

Nelson D, Treguer P (1992) Role of silicon as a limiting nutrient to Antarctic diatoms: evidence from kinetic studies in the Ross Sea ice-edge zone. Mar Ecol Progr Ser 80:255-264

Oswald G, Robin GQ (1973) Lakes beneath the Antarctic ice sheet. Nature 245:251-254

Oyama M, Takehara H (2005) Revised Standard Soil Color Charts: 27th edition (ed. The Ministry of Agriculture, Forestry and Fisheries of Japan)

Priscu JC, Adams EE, Lyons WB, Voytek MA, Mogk DW, Brown RL, McKay CP, Takacs CD, Welch KA, Wolf CF, Kirshtein JD, Avci R (1999) Geomicrobiology of subglacial ice above Lake Vostok, Antarctica. Science 286:2141-2144 
Raiswell R (1984) Chemical models of solute acquisition in glacial meltwaters. J Glaciol 30:49-57

Raiswell R, Canfield DE (2012) The iron biogeochemical cycle past and present. Geochem Perspect 1:1-322

Reimer PJ, Baillie MGL, Bard E, Bayliss A, Beck JW, Bertrand CJH, Blackwell PG, Buck CE, Burr GS, Cutler KB, Damon PE, Edwards RL, Fairbanks RG, Friedrich M, Guilderson TP, Hogg AG, Hughen KA, Kromer B, McCormac G, Manning S, Ramsey CB, Reimer RW, Remmele S, Southon JR, Stuiver M, Talamo S, Taylor FW, van der Plicht J, Weyhenmeyer CE (2004) IntCal04 terrestrial radiocarbon age calibration, 0-26 cal kyr BP. Radiocarbon 46:1029-1058

Reimer PJ, Baillie MG, Bard E, Bayliss A, Beck JW, Blackwell PG, Bronk RC, Buck CE, Burr GS, Edwards RL (2009) IntCal09 and Marine09 radiocarbon age calibration curves 0-50,000 years cal BP. Radiocarbon 51:1111-1150

Robin GQ, Swithinbank C, Smith B (1970) Radio echo exploration of the Antarctic ice sheet. Inter Assoc Sci Hydrol Publ 86:97-115

Satish-Kumar M, Wada H (2000) Carbon isotopic equilibrium between calcite and graphite in Skallen Marbles, East Antarctica: Evidence for the preservation of peak metamorphic temperatures. Chem Geol 166:173-182

Sawagaki T, Hirakawa K (1997) Erosion of bedrock by subglacial meltwater. Geografiska Annaler Series a-Phys Geogr 79A, Soya Coast, East Antarctica, pp 223-238

Shaw J (2002) The meltwater hypothesis for subglacial bedforms. Quaternary Inter 90:5-22

Shiraishi K, Hiroi Y, Motoyoshi Y (1987) Plate tectonic development of Late Proterozoic paired metamorphic complexes in eastern Queen Maud Land East Antarctica. Geophys Monogr Ser 40:309-318

Siegert M (2000) Antarctic subglacial lakes. Earth-Sci Rev 50:29-50

Siegert MJ, Dowdeswell J, Gorman M, McIntyre N (1996) An inventory of Antarctic subglacial lakes. Antarctic Sci 8:281-286

Siegert MJ, Carter S, Tabacco I, Popov S, Blankenship DD (2005) A revised inventory of Antarctic subglacial lakes. Antarctic Sci 17:453-460

Siegert MJ, Royston-Bishop G, Woodward J (2012) Antarctic subglacial lakes. Encyclopedia of lakes and reservoirs. Springer, London, pp 37-39

Stuiver M, Reimer PJ (1993) Extended ${ }^{14} \mathrm{C}$ data base and revised Calib $3.0{ }^{14} \mathrm{C}$ age calibration program. Radiocarbon 35:215-230

Stuiver M, Reimer PJ, Braziunas TF (1998) High-precision radiocarbon age calibration for terrestrial and marine samples. Radiocarbon 40:1127-1151

Stumpf A, Elwood Madden M, Soreghan G, Hall B, Keiser L, Marra K (2012) Glacier meltwater stream chemistry in Wright and Taylor Valleys, Antarctica: significant roles of drift, dust and biological processes in chemical weathering in a polar climate. Chem Geol 322:79-90

Takano Y, Tyler J, Kojima H, Yokoyama Y, Tanabe Y, Sato T, Ogawa ON, Ohkouchi N, Fukui M (2012) Holocene lake development and glacial-isostatic uplift at Lake Skallen and Lake Oyako, Lützow-Holm Bay, East Antarctica: based on biogeochemical facies and molecular signatures. Appl Geochem 27:2546-2559

Tayasu I, Hirasawa R, Ogawa NO, Ohkouchi N, Yamada K (2011) New organic reference materials for carbon and nitrogen stable isotope ratio measurements provided by Center for Ecological Research, Kyoto University, and Institute of Biogeosciences, Japan Agency for Marine-Earth Science and Technology. Limnol 12:261-266

Tranter M, Skidmore M, Wadham J (2005) Hydrological controls on microbial communities in subglacial environments. Hydrol Processes 19:995-998

Verleyen E, Hodgson DA, Sabbe K, Cremer H, Emslie SD, Gibson J, Hall B, Imura S, Kudoh S, Marshall GJ, McMinn A, Melles M, Newman L, Roberts D, Roberts SJ, Singh SM, Sterken M, Tavernier I, Verkulich S, de Vyver EV, Van Nieuwenhuyze W, Wagner B, Vyverman W (2011) Post-glacial regional climate variability along the East Antarctic coastal margin: evidence from shallow marine and coastal terrestrial records. Earth-Sci Rev 104:199-212

Watanabe T, Kojima H, Takano Y, Fukui M (2013) Diversity of sulfur-cycle prokaryotes in freshwater lake sediments investigated using aprA as the functional marker gene. Syst Appl Microbiol 36:436-443

Williams W, Sherwood J (1994) Definition and measurement of salinity in salt lakes. International J Salt Lake Res 3:53-63

Wingham D, Siegert M, Shepherd A, Muir A (2006) Rapid discharge connects Antarctic subglacial lakes. Nature 440:1033-1036

Yamane M, Yokoyama Y, Miura H, Maemoku H, Iwasaki S, Matsuzaki H (2011) The last deglacial history of Lutzow-Holm Bay, East Antarctica. Journal of Quaternary Sci 26:3-6

Yokoyama Y, Esat TM (2011) Global climate and sea level enduring variability and rapid fluctuations over the past 150,000 years. Oceanogr 24:54-69
Yokoyama Y, Miyairi Y, Matsuzaki H, Tsunomori F (2007) Relation between acid dissolution time in the vacuum test tube and time required for graphitization for AMS target preparation. Nuclear Instr Methods Phys Res Sec B 259:330-334

Yoshida Y, Moriwaki K (1979) Some consideration on elevated coastal features and their dates around Syowa Station, Antarctica. Memoirs Nat Inst Polar Res 13:220-226

Yoshikawa T, Toya H (1957) Report on geomorphological results of the Japanese Antarctic Research Expedition, 1956-1957. Antarctic Record 1:1-13

Young GM, Nesbitt HW (1998) Processes controlling the distribution of Ti and Al in weathering profiles, siliciclastic sediments and sedimentary rocks. J Sediment Res 68:448-455

\section{Submit your manuscript to a SpringerOpen ${ }^{\odot}$ journal and benefit from:}

- Convenient online submission

- Rigorous peer review

- Immediate publication on acceptance

- Open access: articles freely available online

- High visibility within the field

- Retaining the copyright to your article

Submit your next manuscript at $\gg$ springeropen.com 